\title{
African Union and the Politics of Selective Prosecutions at the International Criminal Court
}

\author{
Fabrice Tambe Endoh*
}

\begin{abstract}
The African Union (AU) claims that the International Criminal Court (ICC) is selective against African leaders. The issue therefore arises concerning the validity of the allegations of selectivity. Partly because of such concerns, African Heads of States adopted the Malabo Protocol during their annual summit held in June 2014. Article 46A bis of the Protocol provides immunity for sitting Heads of States. This provision contradicts Article 27 of the Rome Statute and, consequently, arguably reverses the progress made so far in international criminal law by giving priority to immunity in the face of impunity. This article considers the validity of some of the allegations of selective application of criminal sanctions by the ICC and the likely consequence of the Malabo Protocol for regional and international criminal justice. The article argues that the Malabo Protocol should not be ratified by African states until the shield of immunity granted to sitting Heads of States is lifted to better advance the interests of justice for the victims of international crimes in Africa. In addition, the complementarity clause stated in the Malabo Protocol should have a nexus with the ICC such that the Court would be allowed to prosecute the perpetrators of international crimes in circumstances where the African Court of Justice and Human Rights (ACJHR) prove reluctant to do so.
\end{abstract}

Keywords: African Union (AU), United Nations Security Council (UNSC), International Criminal Court (ICC), immunity, impunity.

We are not against international [criminal] justice. It seems Africa has become a laboratory to test the new international law.

His Excellency Jean Ping, Former Chairperson, African Union Commission. ${ }^{1}$

* Dr. Fabrice Tambe Endoh holds a PhD in International Criminal Law from the North-West University, South-Africa.

1 See BBC News, "Vow to pursue Sudan over "crimes", 27 September 2008. Available at: news.bbc.co.uk/2/hi/africa/7639046.stm (last accessed 1 April 2019). 


\section{Introduction}

This article discusses the allegations of selective application of international criminal law and the political controversies affecting the relationship between the African Union (AU) and the International Criminal Court (ICC). It argues that, while glaring examples of selectivity might seem evident in the works of the ICC, the Court's operations in many instances have been justified by legal necessities. ${ }^{2}$ The article provides an introduction on the allegations of biased prosecution of African leaders by the ICC. Furthermore, justification for the ICC's operations as well as for the United Nations (UN) Security Councils' authority to refer situations to the ICC in line with its mandate arising from Article 13(b) of the Rome Statute are discussed. Also, the author analysed the misuse of the Security Council's deferral authority arising from Article 16 of the Rome Statute. After analysing the allegations of selectivity and the justifications thereof, the article proceeds to discuss the Malabo Protocol, highlighting the strengths and weaknesses, including suggestions for reform.

It is relevant to point out that the indictment of the Sudanese President constitute one among other factors that catalysed the controversial relationship between the AU and the ICC. ${ }^{3}$ The AU also expressed concerns over the warrant of arrest issued against the late Muammar Gaddafi of Libya by stating that such actions compromised the government's initiated efforts aimed at stabilizing the country and created the political atmosphere in which the Gaddafi regime was subsequently overthrown, a defeat that created more problems than solutions for Libyans. ${ }^{4}$ The AU had similarly argued that the continued prosecution of the President of Kenya and his deputy undermined the country's sovereignty and compromised its ability to champion the fight against terrorism in East Africa. ${ }^{5}$

Based on these and other concerns, the AU encouraged its members to find African solutions to African problems by adopting the Malabo Protocol during its 2014 summit held in Equatorial Guinea. ${ }^{6}$ While the effort constitutes a significant mile stone in the fight against impunity, Article 46A bis of the Protocol pro-

2 S. Odero 'Politics of international criminal justice, the ICC's arrest warrant for Al-Bashir and the African Union's neo-colonial conspirator thesis', in C. Murungu \& J. Biegon (Eds.), Prosecuting International Crimes in Africa, Pretoria University Law Press, 2011, p. 145.

3 See Doc. Assembly/AU/Dec 243-267 (XIII) (2009), 13th Assembly of the African Union Summit in July 2009 when the Union voted by a large majority not to cooperate with the ICC over the indictment of the Sudanese President; see also, C. Jalloh, Regionalizing International Criminal Law? International Criminal Law Review, Vol. 9, 2009, p. 445.

4 S. Batohi 'Africa and the International Criminal Court: A prosecutor's perspective' in G. Werle, L. Fernandez \& M. Vormbaum (Eds.), Africa and the International Criminal Court, International Criminal Justice Series, Vol. 1, The Netherlands, TMC Asser Press, 2014, p. 49.

5 C. Jalloh, D. Akande \& M. du Plessis, 'Assessing the African Union Concerns about Art. 16 of the Rome Statute of the International Criminal Court', African Journal of Legal Studies, Vol. 4, 2011, p. 5-50.

6 Draft Protocol on Amendments to the Protocol on the Statute of the African Court of Justice and Human Rights, AU Doc. No. STC/Legal/Min. 7(1) Rev.1, 14 May 2014 [hereinafter 'Malabo Protocol']. 
vides immunity for sitting heads of states. ${ }^{7}$ This provision directly conflicts with Article 27 of the Rome Statute, which provides for equality before the law irrespective of official capacity. ${ }^{8}$ By implication, the construction of Article 46A bis of the Malabo Protocol prioritizes immunity in the face of impunity by providing the necessary clause through which heads of states and top government officials are shielded from prosecution. As a result, the question arises, "whose justice" is the law designed to protect? Is it justice to protect the interest of the victims or to advance the politics of the strong? The logic is, if heads of states, top government officials and powerful nations are still determined to stay away from justice, then the objective of international criminal law has not been achieved. ${ }^{9}$ In subsequent sections of this article, the author interrogates the politics of prosecutions at the ICC, providing competing political debates and legal justifications for the Court's operations in Africa and the world at large.

\section{Security Council Referrals and the Politics of Justice}

It is a fact that the composition of the Security Council is a blend of states that are parties to the Rome Statute as well as states that have not accepted the jurisdiction of the ICC. The trouble is, there is growing concern in terms of decisionmaking regarding the referral of a situation by the UN Security Council. Most often, the debate is centered on the legitimacy of states that have not accepted the jurisdiction of the ICC yet, they participate towards referring situations to the Court by virtue of their permanent membership to the Security Council. ${ }^{10}$ Worst of all, some of the states whose authority within the framework of the Security Council are questioned herein have adopted domestic legislations to preclude cooperation with the ICC. ${ }^{11}$ Such display of double standards does not only jeopardize the Council's authority arising from Article 13(b) of the Rome Statute but as well promote the allegations of selectivity raised by the AU.

The systematic adoption by the USA of domestic legislation precluding cooperation with the ICC speaks to the fact that the USA is not ready to cooperate with, let alone be subjected to the jurisdiction of the ICC. This piece of legislation include the American Service Members' Protection Act (2002), also known as the 'Hague Invasion Act' that provides for a mechanism of penalizing any country

7 Malabo Protocol, Art. 46A bis provides that 'No charges shall be commenced or continued before the Court against any serving AU Head of State or Government, or anybody acting or entitled to act in such capacity, or other senior state officials based on their functions, during their tenure of office'.

8 Rome Statute of the International Criminal Court, text circulated as document A/CONF.183/9 of 17 July 1998. Art. 27.

9 B. Netsanet, Impunity vs Immunity: Africa and the ICC, 2015, available at: www.amnesty.org/en/ latest/news/2015/06/impunity-vs-immunity-africa-and-the-icc/ (last accessed 22 March 2018).

10 Jalloh; Akande \& du Plessis, 2011, p. 5-50.

11 'US Congress Passes Anti-ICC Hague Invasion Act' Coalition for the International Criminal Court, Press Release, 26 July 2002. Available at: www.iccnow.org/documents/07.26.02ASPAthru Congress.pdf (last accessed 15 May 2018). 
that hands over a USA national to the ICC, including the use of military force. ${ }^{12}$ The Act is premised on Scheffer's denunciation of the ICC regime at the Rome diplomatic conference of 1998. Scheffer declared that any USA-ICC treaty relationship is considered unconstitutional because it allows the trial of American citizens for crimes committed on American soil, which are otherwise entirely within the judicial power of the United States. ${ }^{13}$

In a recent escalation of the hostility towards the ICC, the USA threatened to arrest ICC judges who continue to probe war crimes in Afghanistan allegedly committed by USA's soldiers. ${ }^{14}$ In a speech that responded ferociously to a possible ICC investigation of alleged war crimes committed by USA forces in Afghanistan, Bolton threatened to prosecute and sanction ICC personnel involved in the investigation, asserting that the court was "for all intent and purposes .... already dead to us" ${ }^{15}$ In President Trump's Executive Order on blocking property of certain persons associated with the ICC, ${ }^{16}$ the question raised was whether USA personnel involved in atrocity crimes on the territory of a State Party to the Rome Statute escaped the jurisdiction of the ICC because the USA never ratified the treaty? The question boils down to one logical reasoning, USA forces and intelligent personnel can't commit atrocity crimes inside any of the 123 states parties to the Rome Statute without accountability from the ICC. ${ }^{17}$ In light of the punitive measures driven by the USA, the President of the ICC, Chile Eboe-Osuji has accused the USA of acting unlawfully by threatening an economic and legal offensive against the institution. ${ }^{18}$ He further stated that such measures were an attempt at coercion that went against international law as well as domestic law in the USA and elsewhere. ${ }^{19}$ Despite the absurdity of these positions intended to undermine the universality of international criminal law and frustrate the work

12 Ibid.

13 See Statement of David J. Scheffer Ambassador-at-Large for War Crimes Issues and Head of the USA Delegation to the U.N. Diplomatic Conference on the Establishment of a Permanent international Criminal Court. Available at: http://www.iccnow.org/documents/USScheffer_Senate 23July98.pdf (last accessed 30 August 2019).

14 See speech by John Bolton, "The United States threatened to arrest and sanction judges and other officials of the International Criminal Court if it moves to charge any American who served in Afghanistan with war crimes'. Available at: www.france24.com/en/20180910-usa-trumpthreateneds-arrest-icc-judges-american-soldiers-afghan-war-crimes. (last Accessed 31 October 2018). See also, BBC News, ICC 'undeterred' by US sanctions threat. Available at: www.bbc.com/ news/world-us-canada-45487865. (last accessed 31 October 2018).

15 See Bolton's speech. Ibid.

16 See The Self-Defeating Executive Order Against the International Criminal Court. Available at: https://www.justsecurity.org/70742/the-self-defeating-executive-order-against-theinternational-criminal-court/ (last accessed 20 August 2019).

17 Ibid.

18 See The Guardian, 'Head of ICC says US measures to curb court are unlawful'. Available at: https://www.theguardian.com/law/2020/jun/24/head-of-international-criminal-court-accusesus-of-acting-unlawfully (last accessed 20 June 2020).

19 Ibid. In an interview, the President commented "This is unlawful ... In any liberal democracy, or even not so liberal democracies, you pick up a statute book and it will tell you that it is against the law to coerce a court of law in order to have justice the way you want it". Further, he added "Even in the USA itself, the law forbids that form of conduct". 
of the ICC, the USA and allies continue to refer other countries to the ICC by virtue of their membership to the Security Council. ${ }^{20}$

Owing to the adoption of Security Council Resolution 1593 referring the Darfur case file to the ICC and consequently resulting in warrants of arrest issued against the Sudanese President Omar Al-Bashir and other alleged co-perpetrators, the Sudanese government argued that the country's sovereignty was violated both by the Security Council, which referred the matter, and the ICC, which has the duty to implement the decision. ${ }^{21}$ Such reactions from the Sudanese government resulted in a tense relationship with the ICC and following a prosecutorial request of a finding of non-cooperation, the Pre-Trial Chamber issued a decision in May 2010 indicating that Sudan had failed to comply with its obligations to cooperate with the Court and invited the Security Council to take any action it deemed appropriate. ${ }^{22}$ The Security Council has not taken any action.

On its part, the AU, which had previously engaged with Sudanese authorities in a diplomatic process of mediation with the aim of finding a political solution to the Darfur crisis, called on the Security Council to invoke its Article 16 mandate arising from the Rome Statute and defer ICC proceedings against Al-Bashir. ${ }^{23}$ The AU's request was hinged upon the need to encourage such mediation efforts which already attracted the attention and cooperation of the various factions involved in the conflict. ${ }^{24}$ Given that the Security Council failed to consider the deferral request from the AU, African Heads of States directed all AU Member States to withhold cooperation from the ICC regarding the arrest and surrender of President Al-Bashir. ${ }^{25}$ The decision adopted in its 13th summit in July 2009 at Sirte, Libya, was indicative of the AU's frustration regarding the Security Council's refusal to defer ICC proceedings against Sudan's Al-Bashir. ${ }^{26}$

Based on the Security Council's reluctance to invoke Article 16 to defer proceedings against Al-Bashir, including a seemingly passive attitude towards serious crimes committed in other regions of the world, the AU argued that Security Council referrals are motivated by self-interest and global politics, thereby raising the question as to why Sudan and not Syria? While the Security Council was quick to refer the Libya and Sudanese situations to the ICC, it continues to be reluctant

20 Odero, 2011, p. 145.

21 UN Security Council 64th Sess., 6096th meeting, UN Doc. S/PV.6096, 3-4, 15 March 2009.

22 See Prosecutor v. Ahmad Harun and Ali Kushayb, Case No. ICC-02/05-01/02, Decision May 25 May, 2010 notifying the Security Council of the lack of cooperation by the Republic of Sudan.

23 See Communique of the 207th Meeting of the Peace and Security Council at the Level of the Heads of State and Government, Doc. PSC/ AHG/COMM.1(CCVII), 29 October, 2009. para. 5.; See also, Decision of the Meeting of African States Parties to the Rome Statute of the International Criminal Court, Doc. Assembly/AU/13 (XIII), Addis Ababa, 1-3 July, 2009. para. 8.

24 Jalloh, Akande \& du Plessis, 2011. p. 5-50.

25 See 'Decision of the Meeting of African States Parties to the Rome Statute of the International Criminal Court', Press Release, 14 July, 2009. Available at: reliefweb.int/report/sudan/decisionmeeting- african-states-parties-rome-statute-international-criminal-court-icc (last accessed 14 March 2018). 
to refer the situation obtaining in Syria to the Court. ${ }^{27}$ There have been calls for the actions of the government of Bashar al-Assad to be investigated by the Court, including by UN officials and even the General Assembly. ${ }^{28}$ Unfortunately, political divisions between some of the permanent members (Russia, USA and China) have continued to be a stumbling block to such initiatives and consequently the victims of serious crimes in Syria have been left without a legal remedy and the question 'justice is for whom', continues to feature on the spotlight. ${ }^{29} \mathrm{~A}$ broader study conducted by Tambe Endoh and Melvin Mbao, ${ }^{30}$ argues that the political nature of Security Council referrals as portrayed in the character of states bestowed with veto powers seem to have compromised the credibility of the Council's authority arising from Article 13(b) of the Rome Statute and as well advanced the practice of selectivity in the pursuit of international criminal justice.

Despite the available legal framework mandating the Security Council to ensure global peace and security, it has continued to ignore conflicts that threaten both regional and international peace. Article 24 of the UN Charter authorizes the Council to maintain international peace and security on behalf of all UN Member States. ${ }^{31}$ By virtue of Article 25 of the UN Charter, all UN Member States are bound by the Council's decision when it acts on their behalf. ${ }^{32}$ In order to ensure an effective response, Article 39 of the Charter confers upon the Council the mandate to determine threats to regional and international peace and decide what measures shall be taken in accordance with Articles 41 and 42 of the Charter. ${ }^{33}$ Given that such legal obligations exist within the Council's operational framework as provided for by the UN Charter, Article 13(b) of the Rome Statute provides the basis upon which the Council can make determinations in accordance with its Chapter VII mandate and refer such situations to the ICC for prosecution. ${ }^{34}$ So far, the Council has referred two cases from Africa (Sudan and Libya) to the ICC and ignored situations in countries like Iraq and Afghanistan involving the use of drones to launch air strikes which actually resulted in massive deaths.

In March 2003, the USA invaded Iraq with massive air strikes from drones and related sophisticated military weapons. ${ }^{35}$ The military attack was conducted

27 V. Dlamini, 'Deep Read: Justice? That's rich, coming from the ICC', 2012. Available at: mg.co.za/ article/2012-07-03-icc-credibility (last accessed 14 March 2018).

28 M. Heinrich, 'One War Many Reasons: The US Invasion of Iraq', 2015. Available at: www.eir.info/2015/03/09/one-war-many-reasons-the-us-invasion-of-iraq/ (last accessed 14 March 2018).

29 Dlamini, 2012.

30 See F. Tambe Endoh, Selective morality in the pursuit of international criminal justice with particular reference to Article 13 of the Rome Statute ( $\mathrm{PhD}$ thesis, North-West University Institutional Repository, Potchefstroom) forthcoming.

31 See Charter of the United Nations and Statute of the International Court of Justice, [hereinafter UN Charter], 1945.

32 Ibid.

33 Ibid.

34 See Rome Statute of the International Criminal Court, 1998.

35 Heinrich, 2015. 
despite large-scale anti-war protest from around the world. ${ }^{36}$ Hence, international law experts and politicians questioned the legality and occupation of Iraq by the USA forces. ${ }^{37}$ For more than a decade, the question remains whether the invasion of Iraq and Afghanistan by the USA and British forces under the Bush and Blair administrations constituted instances of war crimes for which criminal responsibility could be invoked under international law ${ }^{38}$ Whether the individual architects could be held accountable for violating international treaties by orchestrating the torture and killing of thousands of civilians in these countries? ${ }^{39}$

In the absence of a decisive measure from either the Security Council or the ICC, the Malaysian War Crimes Tribunal, a civil society initiative undertaken by Malaysia's former Head of State Mahathir Mohamed, to outlaw the act of war by prosecuting and convicting alleged suspects for serious violations of international humanitarian law evoked war crimes charges against former President George Bush and former Prime Minister Tony Blair in line with the war crimes criteria listed under Article 8 of the Rome Statute. ${ }^{40}$ The War Crimes Commission found that Bush and Blair had participated in the adoption of executive orders and directives to exclude the 1949 Geneva Conventions, the Convention against Torture, the Universal Declaration of Human Rights and the United Nations Charter in relation to the wars launched by the USA and Britain in Iraq and Afghanistan. ${ }^{41}$ So far, the tribunal remains the first war crimes commission to make judicial pronouncements based on the facts and evidence gathered from the situation that obtained in Iraq and Afghanistan. ${ }^{42}$

While the Security Council and the ICC proved reluctant to take decisive measures regarding the situations obtaining in Iraq, Afghanistan and Syria, both organs responded without delay to the Libya and Sudanese conflicts. The unity of purpose between the North Atlantic Treaty Organization (NATO), the UN Security Council and the ICC suggested a blur between the political and the judicial that undermines the ICC's independence. ${ }^{43}$ In Libya, the Court demonstrated its willingness to engage in politically motivated indictments masterminded by the Security Council. The fact that the Court is not able to free itself from political interference by powerful nations in the Security Council with veto power rhetoric yet not signatories to the Rome Statute evokes the notion that once again the powerful nations can load the dice to roll in their favour and be spared from judicial scrutiny by the ICC. ${ }^{44}$ Given the selectivity of Security Council referrals to the

36 Ibid.

37 D. Gompert, H. Binnendijk, \& B. Lin, 'The Iraq War: Bush's Biggest Blunder'. Available at: newsweek.com/iraq-war-bushs-biggest-blunder-294411 (last accessed 14 March 2018).

38 Heinrich 2015.

39 Ibid.

40 See Chief Prosecutor of the Kuala Lumpur War Crimes Commission v. George Bush and Anthony Blair, criminal proceeding No. 1-CP-2011, 2011.

41 Ibid.

42 M. Ramakrishnan, 'War Crimes Tribunal Finds Bush and Blair Guilty'. Available at www.globalresearch.ca/war-crimes-tribunal-finds-bush-and-blair-guilty/5478367 (last accessed 14 March 2018).

43 Dlamini, 2012, p. 1.

44 Ibid. 
ICC as evident in cases before the Court, many have resorted to questioning the legality of the Council's authority under Article 13(b) of the Rome Statute. ${ }^{45}$

So far, the most controversial debate concerning the ICC is the question of selectivity with regard to cases tried by the Court. ${ }^{46}$ Such debates emanating from the ICC's primary evaluative audience-states, non-governmental organizations (NGOs), communities most affected by the ICC's work, academics and, more generally, the global community have generated growing concerns about the legitimacy of the ICC regime. ${ }^{47}$ Questions have emerged as to why the Court is quick to indict and probably issue arrest warrants against leaders of Africa for serious crimes and at the same time slow in responding to similar atrocities when committed by Western leaders, in particular, the prosecutor's refusal to investigate war crimes allegedly committed by British soldiers in Iraq. ${ }^{48}$ These glaring examples of selectivity continue to pose the question as to what situation and cases are 'major' enough for ICC adjudication within the context of its mandate to ensure global justice. Admittedly, scholarly attention and advocacy have identified selectivity as a threat to the Court's legitimacy.

\section{Security Council Deferrals and the Allegation of Bias against Africans}

The authority to defer ICC investigations and prosecutions by the UN Security Council had been invoked by the 1994 draft Statute of the International Law Commission (ILC). The Commission stated as follows:

No prosecution may be commenced under this Statute arising from a situation which is being dealt with by the Security Council as a threat to or breach of the peace or an act of aggression under Chapter VII of the Charter, unless the Security Council otherwise decides. ${ }^{49}$

According to the ILC's draft, the ICC would hardly proceed with investigations or prosecutions in matters that fall within the ambit of Chapter VII of the UN Charter. By this determination, the Security Council was conferred with the mandate to drive the activities of the Court in terms of investigations and prosecution. Article 23(3) of the ILC's draft was highly criticized by states which expressed the fear that the ICC's judicial functions would be locked in the whims of the permanent five members of the Security Council (USA, United Kingdom, France, Russia can Union Perspective on Universal Jurisdiction', Criminal Law Forum, Vol. 21, No. 1, 2009, p. 1-65; M. deGuzman, 'Choosing to Prosecute: Expressive Selection at the International Criminal Court', Michigan Journal of International Law, Vol. 33, 2012, p. 265.

46 Ibid.

47 Ibid.

48 W. Schabas, 'Prosecutorial Discretion v. Judicial Activism at the International Criminal Court, Journal of International Criminal Justice, Vol. 6, No. 4, 2008, p. 731-761.

49 Report of the International Law Commission on the work of its forty-sixth session, Draft Statute for an International Criminal Court, UN GAOR Supp. (No. 10), reprinted in 1994, 2 Y.B. Int'l L. Comm'n 49, UN Doc. A/49/10, p. 43-44. 
and China). ${ }^{50}$ The compromise of the ILC's draft, which is reflected under Article 16 of the Rome Statute has become one of the thorniest issues in the international criminal law debate. It is perhaps among the major reasons for the AU's allegation of an ICC bias.

The AU's frustration over the Security Council's failure to invoke Article 16 of the Rome Statute dates back to the adoption of Security Council Resolution 1422. Influenced by the USA in 2002, Resolution 1422 was adopted by the Security Council in its 4572 meeting to invoke Article 16 of the Rome Statute in accordance with its mandate under Chapter VII of the UN Charter. Paragraph 1 of the Resolution makes reference to Article 16 as follows:

Request, consistent with the provisions of Article 16 of the Rome Statute, that the ICC, if a case arises involving current or former officials or personnel from a contributing State not a Party to the Rome Statute over acts or omissions relating to a United Nations established or authorized operation, shall for a twelve-month period starting 1 July 2002 not commence or proceed with investigation or prosecution of any such case, unless the Security Council decides otherwise... ${ }^{51}$

Resolution 1422 was invoked under the authoritative command of the USA owing to the fact that she (USA) had threatened earlier to veto renewal of the mandate of the UN mission in Bosnia and Herzegovina, including all other future operations. ${ }^{52}$ The resolution received criticisms from government representatives who cited the 'deep injustices' of discriminating between peacekeeping forces in terms of investigations and prosecutions before the ICC. ${ }^{53}$ In the view of many, the Rome Statute was indirectly modified without procedural amendment of the treaty. ${ }^{54}$ The criticisms pointed to the politicized nature of Article 16, including the UN Security Council's invocation under the authoritative command and threat by a veto wielding superpower. In the subsequent Resolution 1487 adopted by the Security Council in its 4772 meeting of 12 June 2003, the Netherlands raised concerns about Paragraph 1 of Resolution 1422 by referring to the travaux preparatoires to clarify the intention of the drafts man in relation to Article 16 of the Rome Statute. The Netherlands stated as follows:

50 Jalloh, Akande \& du Plessis, p. 5-50.

51 Security Council Resolution 1422 of 12 July 2002. UN Doc. S/RES/1422. para. 1.

52 See Statement by the United States' representative at the UN Security Council meeting of 10 July 2002. UN Doc. S/PV/4568, at 9-10.

53 Uruguay's representative Felipe Paolillo argued that discriminations among peace keepers results in 'deep injustices'. See UN Security Council's 4772nd meeting of 12 June, 2003. UN Doc. S/PV. 4772.

54 See Letter from the Ambassadors to the United Nations of Canada, Brazil, New Zealand and South Africa to the President of the UNSC in relation to the draft resolution 2.2002.747 currently under consideration by the UNSC under the agenda item Bosnia-Herzegovina, UN Doc. S/2002/754, 12 July 2002. 
Article 16 reads that "no investigation or prosecution may be commenced or proceeded with under this Statute for a period of 12 months after the Security Council, in a resolution adopted under Chapter VII of the Charter of the United Nations, has requested the Court to that effect." From both the text and the travaux preparatoires of this Article follow that this Article allows deferrals - only on a case by case basis; - only for a limited period of time; and only when a threat to or breach of peace and security has been established by the Council under Chapter VII of the UN Charter. In our view, Article 16 does not sanction blanket immunity in relation to unknown future events. ${ }^{55}$

Speaking on behalf of Germany, the German representative added:

Chapter VII of the United Nations Charter requires the existence of a threat to the peace, a breach of peace or an act of aggression-none of which, in our view, is present in this case. The Security Council would thus be running the risk of undermining its own authority and credibility [by adopting the draft Resolution]. ${ }^{56}$

The Canadian representative also explained that Article 16 was to be made available to the UN Security Council only on a limited case-by-case basis. Reflecting on the legislative history of Article 16 of the Rome Statute, the representative of Canada summed up that "most States were opposed to any Security Council interference in ICC actions, regarding it as inappropriate political interference in a judicial process." ${ }^{27}$ The representative of Canada's views were seconded by the representative of Syria, who appealed to the Security Council to assume its responsibility and not accept exemptions that might damage the credibility of the Court even before it was born.

The views expressed above were re-echoed by Heads of States of many other countries who expressed the view that the Council's actions were inconsistent with the provisions of the Rome Statute and could cause severe harm to the credibility and independence of the ICC. ${ }^{58}$ Besides the debates surrounding Resolution 1422, the Security Council, for the second time made reference to Article 16 of the Rome Statute when it referred the Darfur case file to the ICC in 2005, in accordance with Resolution 1593. Paragraph 2 of the resolution's preamble stated:

UN Security Council's 4772nd meeting of 12 June 2003. UN Doc. S/PV.4772.

See UN Security Council's 4568th meeting of 1 July 2002. UN Doc. S/PV.4568.

See Statement by HE. Paul Heinbecker, 'Ambassador and Permanent Representative of Canada to the UN, remarks at the Tenth Session of the Preparatory Commission for the ICC', 3 July 2002. Available at: www.iccnow.org/documents/CanadaICCPlenary3July02.pdf (last accessed 4 April 2019).

58 See XIII Conference of Heads of State or Government of the Non-Aligned Movement, Doc. NAM XIII/Summit/Final Document, available at: cns.miis.edu/nam/documents/Official_Document/ 14NAMSummit-Havana-Compiled.pdf (last accessed 4 April 2019). 
Recalling Article 16 of the Rome Statute under which no investigation or prosecution may be commenced or proceeded with by the International Criminal Court for a period of 12 months after a Security Council request to that effect. Moreover, operative paragraph 6 provides that the UNSC: Decides that nationals, current or former officials or personnel from a contributing State outside Sudan which is not a party to the Rome Statute of the International Criminal Court shall be subject to the exclusive jurisdiction of that contributing State for all alleged acts or omission arising out of or related to operations in Sudan established or authorized by the Council or the African Union, unless such jurisdiction has been expressly waived by that contributing State. ${ }^{59}$

It is argued inter alia that preambular paragraph 2 of Resolution 1593 stated above was included to address the concerns of the USA, which agreed informally to abstain from vetoing the resolution in return. The United States Ambassador to the UN highlighted that the resolution provided protection for USA citizens by stating that "No United States persons supporting the operations in the Sudan will be subjected to investigation or prosecution because of this resolution." 60

From the points discussed above, it is clear that previous instances upon which Article 16 of the Rome Statute was invoked were so done to accommodate the interest of specific members of the Security Council with veto powers. Such political manoeuvrings have been echoed by many other States as potential threats to the ICC's independence and credibility. It is recalled that Article 16 was not intended as a means by which the Security Council could easily undermine the functions of the ICC. ${ }^{61}$ The provision is understood by many states as being limited to deferrals of investigations or prosecutions on a case-by-case basis and probably applicable in circumstances where justice conflicts with peaceful negotiation of conflicts. Therefore, African states had relied on Article 16 deferrals as a solution to political conflicts emanating from Africa. ${ }^{62}$ Rather, the Security Council gradually became an obstacle to Africa's quest for peace as it failed to defer ICC investigations and prosecutions of conflict situations in Africa. The Council refused to defer the Sudanese situation against President Omar Al-Bashir despite numerous calls for the Court to allow for a diplomatic settlement to the conflict in Darfur. ${ }^{63}$

Calling on all African states not to cooperate with the ICC towards the arrest and surrender of Al-Bashir, the AU cited Article 98 of the Rome Statute that deals

59 See Security Council Resolution 1593 of 31 March, 2005 referring the situation in Darfur to the International Criminal Court. UN Doc. S/RES/1593.

60 See Security Council's 5158 meeting of 31 March, 2005. UN Doc. S/PV.5158.

61 J. Okoth, 'Africa, the United Nations Security Council and the International Criminal Court: The Question of Deferrals', in Werle G. Werle, L, Fernandez \& M. Vormbaum (Eds.), Africa and the International Criminal Court; International Criminal Justice Series, Vol. 1, The Netherlands, Springer Publishers, TMC Asser Press, 2014, p. 198.

62 Ibid.

63 Assembly of the African Union, Decision on the Meeting of African States Parties to the Rome Statute of the International Criminal Court (ICC), Assembly/AU/Doc.245(XIII), Sirte, 2009. 
with cooperation with respect to waiver of immunity and consent to surrender as the legal justification for its decision. ${ }^{64}$ Consequently, African states, including states parties to the Rome Statute have reluctantly allowed Al-Bashir to enter and exit their countries despite the ICC's warrants of arrest against him. This pattern of behaviour portrayed by African states is the consequence of the AU's proposal for amendment of Article 16 deferrals under the Rome Statute such that when the Council declines to consider a proposal of a state with regard to deferral, the matter can be decided upon by the General Assembly of the UN. ${ }^{65}$

On 12 October 2013, Kenya, supported by the AU, called on the Security Council to defer proceedings against President Uhuru Kenyatta and his Deputy, William Ruto for crimes committed during the 2007/2008 post-election violence that occurred in Kenya. ${ }^{66}$ Once again the Council declined from adopting a resolution in accordance with Article 16 of the Rome Statute. The AU contested the Council's decision on the grounds that the continuous prosecution of the President and his Deputy undermined the sovereignty, stability and peace of the people of Kenya and also it compromised their ability to champion the fight against terrorism in East Africa. ${ }^{67}$ The failure to adhere to Kenya's request for a draft resolution coupled with past denials by the Council to invoke Article 16 provoked immediate criticisms from the African representatives. ${ }^{68}$ The Kenyan representative expressed total dissatisfaction and stated that the Security Council is '[...] no institutional destination for serving complex and fluid international security and political problems'. ${ }^{69}$

The sequence of events discussed above provides the background against which the AU expressed dissatisfaction with the manner in which the UN Security Council has dealt with the question of deferrals. ${ }^{70}$ Even though the AU continuously argues for peace as the basis for its calls for deferrals, an issue that greatly annoyed the Union is the continuous prosecution of African leaders before the ICC. ${ }^{71}$ This motive could be anchored on the decision of its extraordinary session of October 2013 when the Union reiterated its "concern on the politicization and misuse of indictments against AU leaders." 72 All these arguments form an informative background against which the AU lamented the failure of the UN Security Council to use Article 16 for purposes of justice rather than politics.

69 United Nations Security Council 7060th Meeting, S/PV. 7060, 2013.

70 African Union Assembly, Decision on International Jurisdiction, Justice and the International Criminal Court, Doc. Assembly/AU/13 (XXI), 2013, para. 4.

71 D. Tladi, 'The African Union and the International Criminal Court: the battle for the soul of international law', South African Yearbook of International Law, Vol. 34, 2009, p. 61.

See Rome Statute of the International Criminal Court, Article 98.

Africa Union Assembly, Discussion on Africa's relationship with the International Criminal Court (ICC), Ext/Assembly/AU/Dec., 2013.

Ibid.

United Nations Security Council 7060th Meeting, S/PV. 7060, 'Peace and Security in Africa', 2013

African Union Assembly, Doc. Assembly/AU/13 (XXI), 2013. para. 4. 


\section{Alternative Justifications for ICC's Operations Worldwide}

Although the ICC is criticized to have focused on Africa, ${ }^{73}$ it has conducted preliminary investigations worldwide: "Iraq, Venezuela and Colombia (2006); Afghanistan (2007); Georgia and Sri Lanka (2008); Gaza, Honduras and South Korea (2010)". ${ }^{74}$ However, these investigations have not resulted in any indictment for various reasons: crimes were insufficient in number, national justice systems were able to deal with the situations, investigations are ongoing and/or the ICC cannot legally address some crimes committed in a state not party to the Rome Statute. ${ }^{75}$ Regarding the investigation in Iraq, the former Chief Prosecutor Ocampo decided not to further the investigation on the grounds that the situation did not meet the required gravity threshold. The Prosecutor stated that the crimes committed in Iraq were not severe enough to warrant ICC prosecution. ${ }^{76}$ In 2006, the Prosecutor analysed the clashes in Venezuela that occurred in 2002 between supporters and opponents of former President Hugo Chavez and resolved to reject the idea of a formal investigation. In addition, the ICC pressurized Colombia to make appropriate use of its criminal justice systems. ${ }^{77}$ Concerning the situation in Afghanistan, investigations commenced in 2007 with the Prosecutor affirming that NATO forces, including USA personnel and the Taliban would be investigated. ${ }^{78}$

The ICC has kept close watch and continually monitored the situation that occurred in Georgia in 2008, as well as sending delegations to Georgia and Russia. ${ }^{79}$ The ICC launched an investigation into the use of child soldiers in Sri Lanka in 2008. ${ }^{80}$ Although Sri Lanka has not ratified the Rome Statute, the ICC could potentially have jurisdiction over crimes committed by nationals of states parties on its territory. ${ }^{81}$ The ICC considered investigating war crimes committed in Gaza

73 C. Gegout, 'The International Criminal Court: Limits Potential and Conditions for the Promotion of Justice and Peace', Third World Quarterly, Vol. 34, No. 5, 2013, p. 800.

74 Ibid.

75 ICC, 'Report on Preliminary Examination Activities'. Available at: www.icc-cpi.int/NR/rdonlyres/ C433C462-7C4E-4358-8A72-8D99FD00E8CD/285209/

OTP2012ReportonPreliminaryExaminations22Nov2012.pdf (last accessed 12 September 2018).

76 ICC, 'Letter from the Prosecutor, The Hague', 9 February 2006, p. 9, available at: www2.icccpi.int/NR/rdonlyres/F596D08D-D810-43A2-99BB-B899B9C5BCD2/277422/

OTP_letter_to_senders_re_Iraq_9_February_2006.pdf (last accessed 12 September 2018).

77 A. Guaqueta, 'The way back in: reintegrating illegal armed groups in Colombia then and now', in M. Berdal \& D. H. Ucko (Eds.), Reintegrating Armed Groups after Conflict: Politics, Violence and Transition, Abingdon, Routledge, 2009, p. 31.

78 ICC, 'The Prosecutor of the International Criminal Court, requests judicial authorization to commence an investigation into the situation in the Islamic Republic of Afghanistan', available at: www.icc-cpi.int//Pages/item.aspx?name=171120-otp-stat-afgh (last accessed 12 September 2018).

79 See statement by the Prosecutor of the International Criminal Court, Mrs Fatou Bensouda regarding recent ICC-visit to Georgia. Available at: www.icc-cpi.int/Pages/item.aspx? name=16_02_18_otp-stat (last accessed 12 September 2018).

80 ICC, 'Investigating the use of child soldiers in Sri Lanka'. Available at: www.sundaytimes.lk/ 050807/news/2.html (last accessed 12 September 2018).

81 Ibid. 
in 2010 but could not indict the perpetrators of serious crime committed in Palestine, as these territories did not legally constitute a state. ${ }^{82}$ The ICC opened preliminary examinations on crimes committed during the 2009 coup in Honduras in which, the military ousted President Manuel Zelaya, and on war crimes committed by North Korean forces in the territory of the Republic of Korea in $2010 .{ }^{83}$

The points listed above are arguments in support of the fact that the ICC is actually adopting an outreach strategy to target situations outside of Africa. The Court has clarified that its presence in Africa is influenced by the complementarity principle. ${ }^{84}$ On 10 March 2009, the Pre-Trial Chamber of the ICC made it clear that at the time the ICC instituted proceedings against the LRA leaders, Uganda's national proceedings were not sufficient to warrant the exclusion of such actions from the Court. ${ }^{85}$ This decision was upheld by the Appeals Chamber on 16 September 2009. ${ }^{86}$ Therefore, it is evident that the ICC's proceedings could not be waived since the Government of Uganda could not show proof of a structure to complement the ICC by investigating and prosecuting the suspects. ${ }^{87}$ Similarly, there have been increasing allegations that Nigerian security forces have committed serious violations against citizens while trying to end the terrorist attacks by Boko Haram. ${ }^{88}$ On her visit to Nigeria in 2012, the Chief Prosecutor of the ICC, Fatou Bensouda, stated that the ICC was only conducting preliminary analysis and did not intend to interfere with domestic proceedings provided the government was ready to prosecute those responsible for serious crimes committed in the country. ${ }^{89}$ Nigeria has been listed as one among other countries under preliminary investigation given that the Office of the Prosecutor of the ICC had received several communications since 2005 in relation to the situation prevailing in the country. This situation includes ethnic and religious conflicts that have

82 See ICC's Declaration, Art. 12(3). Available at: www.icc-cpi.int/Menus/ICC/Structure+of+the +Court/Registry/Declarations.htm; and ICC, 'Situation in Palestine', 3 April 2012, http://icccpi.int/NR/rdonlyres/C6162BBF-FEB9-4FAF-AFA9-836106D2694A/284387/

SituationinPalestine030412ENG.pdf (last accessed 12 September 2018).

83 M. Mutua, 'Savages, victims and saviors: the metaphor of human rights', Harvard International Law Journal, Vol. 42, No. 1, 2001, p. 201-242.

84 The Prosecutor v. Joseph Kony, Vincent Otti, Okot Odhiambo and Dominic Ongwen, ICC-02/0401/05 (Decision on the admissibility of the case under Art. 19(1) of the Statute).

85 The Prosecutor v. Joseph Kony, Vincent Otti, Okot Odhiambo and Dominic Ongwen, ICC-02/0401/05.

86 The Prosecutor v. Joseph Kony, Vincent Otti, Okot Odhiambo and Dominic Ongwen, ICC-02/0401/05-408 (Judgement on the appeal of the Defence against the 'Decision on the admissibility of the case under Art. 19(1) of the Statute' of 10 March 2009).

87 O. Maunganidza, 'Uganda's International Crimes Division: A Step in the Right Direction', in H.J. van der Merwe (Ed.), International Criminal Justice in Africa: Challenges and Opportunities, Berlin, Konrad Adenauer Stiftung, 2014, p. 57.

88 The Economist, 'Nigeria's crisis: A threat to the entire country', The Economist, 29 September 2012, available at: www.economist.com/node/21563751 (last accessed 14 February 2019).

89 B. Olugbo, 'Nigeria and the International Criminal Court', in H.J. van der Merwe (Ed.), International Criminal Justice in Africa: Challenges and Opportunities, Berlin, Konrad Adenauer Stiftung, 2014, p. 83. 
affected the central region of the country since 2004 and violent clashes after the parliamentary and presidential elections in $2011 .^{90}$

While debates continue to mount on the subject of selective application of criminal sanctions, pro-ICC activists have argued that the ICC's involvement in Africa is justified on the basis of complementarity and not selectivity. While the International Criminal Tribunal for the Former Yugoslavia (ICTY), the International Criminal Tribunal for Rwanda (ICTR) and the Special Court for Sierra Leone (SCSL) had primacy over domestic courts, the ICC gives primacy to domestic courts by complementing and not supplanting genuine national proceedings. ${ }^{91}$ The principle of complementarity fosters respect for the primary jurisdiction of states as well as practical considerations of efficiency given that states generally have the best access to the evidence, witnesses and resources and will therefore be in the best position to carry out the proceedings. As long as a state is able and willing genuinely to investigate and prosecute a matter, the ICC does not have jurisdiction. ${ }^{92}$ This is in compliance and furtherance of the objectives of the Rome Statute, which affirms that "the most serious crimes of concern to the international community must not go unpunished and that their effective prosecution must be ensured by taking measures at the national level and by enhancing international cooperation." 93 Despite outstanding challenges posed by the AU to the ICC regime, ${ }^{94}$ some African states have continued to support the work of the Court by signing and ratifying the Rome Statute. For example, Ivory Coast was warmly welcomed by the ICC on 18 March 2013 as the 122nd state party to the Rome Statute. ${ }^{95}$

While powerful states like the USA seem not to have endorsed the ICC, they show indirect support for the Court. The fact that the USA did not veto resolution 1593 and 1970 referring the situations in Sudan and Libya indicated that the USA and other superpowers indirectly favoured the functions of the ICC. ${ }^{96}$ On Monday, 18 March 2013, Bosco Ntaganta, the Congolese warlord indicted by the ICC surrendered himself to the USA Embassy in Rwanda. The Embassy did not reject his gesture, but rather, he was transferred to The Hague for subsequent prosecution by the ICC. This incident underscored the fact that the USA considers the

90 International Criminal Court, 'The Office of the Prosecutor: Report on Preliminary Examination Activities', 13 December 2011, available at: https://www.icc-cpi.int/NR/rdonlyres/ 63682F4E-49C8-445D-8C13-F310A4F3AEC2/284116/OTPReportonPreliminaryExaminations

13December2011.pdf (last accessed 13 February 2013).

91 Rome Statute of the International Criminal Court, Art. 17.

92 Art. 19 of the Rome Statute provides that 'The Court shall satisfy itself that it has jurisdiction in any case brought before it. The Court may, on its own motion, determine the admissibility of a case in accordance with Art. 17'.

93 See Preamble of the Rome Statute, para. 4.

94 See AU Resolution adopted on 3 July 2009, in Sirte, Libya, calling on African States not to enforce the ICC warrant of arrest against President Al-Bashir of Sudan.

95 The Rome Statute entered into force for Ivory Coast on 1 May 2013.

96 G. Kemp, 'Tacking stock of International Criminal Justice in Africa-Three inventories considered in H.J. van der Merwe (Ed.), International Criminal Justice in Africa: Challenges and Opportunities, Berlin, Konrad Adenauer Stiftung and Authors, 2014, p. 7. 
ICC to be a legitimate role player in the fight against impunity.$^{97}$ Furthermore, France's envoy to the UN General Assembly, declared that the Security Council referrals to the ICC constituted recognition of the Court as a 'key actor on the international stage' ${ }^{98}$ While it is arguably more realistic to depict the ICC as an important role player in the international scene, its functions are still being subdued by the whims of the most important military and economic powers, notably the USA, China and the Russian Federation. ${ }^{99}$

\section{Security Council Referrals and the Defence of Immunity Regarding Al- Bashir}

It is acknowledged that Article 27(2) of the Rome Statute has neutralized the immunity granted to senior officials from states that are parties to the Rome Statute. ${ }^{100}$ However, immunities granted to officials of non-states parties are not affected by Article 27(2) of the Statute because the states have not signed and ratified the treaty. From this premise, a distinction is drawn between immunities accruing to officials of non-states parties from that which is afforded to officials of states parties to the ICC. However, such distinctions in terms of jurisdiction and admissibility do not apply when a case is referred to the ICC by the UN Security Council in accordance with its Chapter VII mandate arising from the UN Charter. ${ }^{101}$ The first arrest warrant issued against President Omar Al-Bashir in 2009 was a consequence of the UN Security Council referral of the situation in Darfur in accordance with its Chapter VII mandate. ${ }^{102}$ Thereafter, the Pre-Trial Chamber held that in line with Article 27 of the Rome Statute, President Omar Al-Bashir's position as Head of State not party to the Rome Statute had no effect on the Court's jurisdiction over the case. ${ }^{103}$

It is important to differentiate the exercise of jurisdiction by an international criminal court as opposed to the jurisdiction of national authorities over such officials. From this point of view, it can be argued that the question of immunity with regard to Security Council referrals comes on two levels and to limit the

97 See Statement by the Prosecutor of the ICC on 22 March 2013. Available at: www.icc-cpi.int/ en_menus/icc/press\%20and\%20media/press\%20releases/Pages/rstatement-22-03-2013.aspx (last accessed 21 August 2018).

98 See C. Lynch, 'The world's court vs the American right', Foreign Policy, available at: turtlebay.foreignpolicy.com/posts/2013/02/11/the_icc_vs_americanconservatives (last accessed 21 August 2018).

99 Kemp, 2014, p. 7.

100 See Prosecutor v. Omar Al-Bashir, Pre-Trial Chamber I, decision pursuant to Art. 87(7) of the Rome Statute on the failure by the Republic of Malawi to comply with the cooperation requests issued by the Court with respect to the arrest and surrender of Omar Al-Bashir, 13 December 2011, para. 18.

101 E. Trendafilova, 'Africa and the International Criminal Court: A judge's perspective', in G. Werle \& M. Vormbaum (Eds.), Africa and the International Criminal Court: International Criminal Justice Series, Vol. 1, The Netherlands, Springer Publication, TMC Asser Press, 2014, p. 30.

102 See Security Council Resolution 1593, Doc. S/RES/1593 (2005).

103 See The Prosecutor v. Omar Al-Bashir, Pre-Trial Chamber I, Decision on the Prosecution's application for a warrant of arrest against Al-Bashir, 4 March 2009. para. 41. 
debate on the basis that the ICC simply has jurisdiction over sitting Heads of States does not exhaust the issue. With regard to the case concerning President Omar Al-Bashir, for instance, the ICC had the duty to obtain custody of the President at least during the trial phase. ${ }^{104}$ By this requirement, the question of immunity from arrest by national authorities emerged. Faced with this imminent challenge posed by the question of immunity at the national level, Pre-Trial Chamber I of the ICC requested the registry to call on states parties, including UN Security Council members that are not parties to the Rome Statute to cooperate towards the arrest and surrender of President Omar Al-Bashir. ${ }^{105}$ Also, the Court called on state parties to cooperate towards the arrest and surrender of President Omar Al-Bashir. ${ }^{106}$

After the issuance of arrest warrants in 2009, President Omar Al-Bashir visited among other states, Chad (in 2010, 2011 and 2013), Malawi (in 2011), South Africa (in 2015) and Jordan (in 2017). By virtue of their membership to the Rome Statute, these states were duty bound to enforce the Court's order and execute the arrest of the President pursuant to Articles 86 and 89 of the Rome Statute. However, they failed to do so. To justify their omission, Malawi, for example, made reference to the immunity of Heads of State that are not parties to the Rome Statute, as well as the AU's position towards the arrest warrant issued against the Sudanese President. ${ }^{107}$ Malawi argued that Article 27 did not compel states that were not parties to the Rome Statute. ${ }^{108}$ Furthermore, Malawi cited the provisions of Article 98(1) of the Rome Statute which is to the effect that the Court may not proceed with a request for surrender or assistance that imposes a duty on the requested state to act inconsistently with its obligations under international law with respect to the state or diplomatic immunity of a person or property of a third state which is not party to the Rome Statute. ${ }^{109}$

In response to Malawi's justification, the Pre-Trial Chamber of the ICC issued a number of decisions on the visits of the Sudanese President to state parties, as well as states which are not parties to the Rome Statute. The first decision came in 2010 when Pre-Trial Chamber I notified the Assembly of States Parties (ASP)

104 See Rome Statute of the International Criminal Court, 1998. Art. 63(1) provides that the PreTrial Chamber shall conduct hearing in the presence of the accused and his counsel. However, Art. 63(2) further stipulates that such a condition may be waived under specific circumstances provided by the Statute.

105 The Prosecutor v. Omar Al-Bashir, 2009, para. 93.

106 See Rome Statute of the International Criminal Court, 1998. Art. 63(1) provides that the PreTrial Chamber shall conduct hearing in the presence of the accused and his counsel. However, Art. 63(2) further stipulates that such a condition may be waived under specific circumstances provided by the Statute.

107 The Prosecutor v. Omar Al-Bashir, Pre-Trial Chamber I, decision in accordance with Art. 87(7) of the Rome Statute on Malawi's non-compliance with the ICC's request to arrest and surrender AlBashir, 13 December 2011, para. 8 and Annex 1.

108 The Prosecutor v. Omar Hassan Ahmad Al-Bashir, ICC-02/05-01/09-139-Corr. Corrigendum to the decision Pursuant to Art. 87(7) of the Rome Statute on the Failure by the Republic of Malawi to Comply with the Cooperation Requests Issued by the Court with respect to the arrest and surrender of Omar Al-Bashir.

109 The Prosecutor v. Omar Hassan Ahmad Al-Bashir, ICC-02/05-01/09-139-Corr. para. 8. 
and the UN Security Council of President Omar Al-Bashir's 2010 visit to Chad. ${ }^{110}$ The Chamber further stated on 12 and 13 December 2011 that Malawi and Chad failed to consult with the Court and therefore breached their obligations arising from the Rome Statute. ${ }^{111}$ Also, both countries where blamed for failing to bring the issue concerning President Omar al-Bashir before the Chamber for proper determination as prescribed by Article 119(1) of the Rome Statute. ${ }^{112}$ The PreTrial Chamber I concluded that Malawi and Chad undermined the Court's mandate arising from the Rome Statute by failing to comply with the Court's decisions. ${ }^{113}$ Consequently, the Chamber initiated the non-compliance procedure by referring Malawi and Chad to the ASP and UN Security Council. ${ }^{114}$ The Chamber argued that the principle of immunity had been rendered ineffective by the very nature and purpose of the ICC-to end a culture of impunity for serious crimes in international law. ${ }^{115}$ In this regard, the Chamber concluded that the Rome Statute's provision under Article 98(1) was inapplicable. ${ }^{116}$

While Malawi and Chad raised the defence of immunity stated under Article 98(1) of the Rome Statute as justification for failing to arrest Al-Bashir, South Africa was rather faced with the decision to choose between the rock and the hard place. During the 25th Summit of the AU, South Africa was caught on the horns of a dilemma when faced with competing obligations from the ICC to arrest AlBashir and the AU's quest to protect sitting Heads of State. ${ }^{117}$ It was hoped that the 25th Summit of the AU held in Johannesburg, South Africa would provide a good opportunity for South Africa to live up to its obligations arising from the Rome Statute to arrest and surrender Al-Bashir to The Hague for prosecution. Unfortunately, South Africa failed to deliver due to its commitment to the AU to

110 The Prosecutor v. Omar Al-Bashir, Pre-Trial Chamber I, decision informing the UN Security Council and the Assembly of the States Parties to the Rome Statute about Al-Bashir's recent visit to the Republic of Chad, 27 August 2010.

111 See Rome Statute of the International Criminal Court, 1998. Art. 97.

112 The Prosecutor v. Omar Hassan Ahmad Al-Bashir, ICC-02/05-01/09-139-Corr. para. 12. See also Prosecutor v. Omar Al-Bashir, Pre-Trial Chamber I, Decision pursuant to Article 87(7) of the Rome Statute on the refusal of the Republic of Chad to comply with the cooperation requests issued by the Court with respect to the arrest and surrender of Omar Al-Bashir, para. 8 (hereinafter Chad non-compliance Decision).

113 The Prosecutor v. Omar Hassan Ahmad Al-Bashir, ICC-02/05-01/09-139-Corr. para. 21; and Chad non- compliance decision, para. 8.

114 The Prosecutor v. Omar Hassan Ahmad Al-Bashir, ICC-02/05-01/09-139-Corr.

115 Ibid., para. 22-36.

116 Ibid., para. 37-43. In the Malawi decision which was issued a day before the Chad decision, the 'Chamber finds that customary international law creates an exception to Head of States immunity when international courts seek a Head of State's arrest for the commission of international crimes. There is no conflict towards Malawi's obligation towards the Court and its obligation under customary international law; therefore, Art. 98(1) of the Statute does not apply', para. 43.

117 Prosecutor v Omar Hassan Ahmed Al-Bashir (Decision following the Prosecutor's Request for an Order Further Clarifying that the Republic of South Africa is Under the Obligation to Immediately Arrest and Surrender Omar Al-Bashir), ICC-02/05-01/09-242. 
protect sitting Heads of State. Consequently, South Africa was summoned to appear before the ICC on 7 April 2017 for failing to arrest Al-Bashir. ${ }^{118}$

The finding of the ICC upon which South Africa was blamed was based on the fact that domestic courts had already issued an order for the arrest of Al-Bashir. Following the request from the Southern African Litigation Centre, the North Gauteng High Court ruled on 15 June 2015 that Al-Bashir should be arrested and detained until he is transferred to The Hague. ${ }^{119}$ The Court also found that the South Africa's Implementation Act removes head of state immunity for the crimes stated under the Rome Statute. The Court held that "the immunity that might have attached to President Bashir as Head of State is excluded or waived in respect of crimes and obligations under the Rome Statute". ${ }^{120}$

At the level of the Supreme Court of Appeal (SCA), the Court acknowledged the statement of the Former Director General at the Department of Justice and Constitutional Development, Nonkululeko Sindane, who mentioned that after South Africa agreed to host the AU Summit in June 2015, it entered into an agreement as the host State with the Commissioner of the AU relating to organization of different meetings schedule to take place at the Summit including the 25th Assembly of the AU. ${ }^{121}$ Based on the hosting agreement, President Al-Bashir had been invited to attend the Summit by the AU and not by the government. The Former Director General then referred to Article VIII of the hosting agreement, guided 'Privileges and Immunities':

The Government shall afford the members of the Commission and Staff Members, delegates and other representatives of the Inter-Governmental Organizations attending the meeting the privileges and immunities set forth in sections $C$ and D, Article VI of the General Conventions on the Privileges and Immunities of the [Organization of the Africa Unity (OAU)]. ${ }^{122}$

In late 2016, South Africa was summoned to explain its failure to arrest Al-Bashir. In making its case before ICC judges, during the public hearing in April 2017, South Africa invoked its obligations arising from the hosting agreement with reference to 'Privileges and immunities'. It explained that diplomatic immunities stated under Article 98(1) of the Rome Statute relating to Al-Bashir's status as a

118 See B. Madhomu, 2017 'As It Happened: SA Appears before ICC over Failure to Arrest Sudan's Bashir, available at: www.news24.com/Africa/News/live-sa-appears-before-icc-over-failure-toarrest-sudans-bashir-20170407 (last accessed 16 April 2017).

119 Southern Africa Litigation Centre v Minister of Justice and Constitutional Development, Case No. 27740/2015, para. 2.

120 Ibid.

121 See The Minister of Justice and Constitutional Development v. The Southern African Litigation Center 9867/15)[2016]ZASCA17, judgment of the Supreme Court of Appeal, Case No. 867/15 of 15 March 2016.

122 See Hosting Agreement between the Commission of the African Union (AUC) and the Government of the Republic of South Africa on the material and technical organization of the Summit on the African Diaspora, Sandton Convention Center, Johannesburg, South Africa. No. 35376. Available at: www.gov.za/sites/default/files/35376_gon409.pdf (last accessed 10 November 2018). 
Head of State and those afforded to attendees of the AU Summit prevented it from executing the arrest. ${ }^{123}$ The government chose to respect the position of the AU stated under the Unions Convention on the Privileges and Immunities despite being faced with competing obligations between the ICC and the AU. The PreTrial Chamber ruled that South Africa failed to comply with its obligation to arrest Al-Bashir by welcoming him for a summit of the AU two years earlier. ${ }^{124}$ The Chamber's decision was received with no surprise given that the Court had repeatedly ruled before that Al-Bashir does not enjoy immunity from arrest and that all states have an obligation to arrest him.

What made the decision pointing is the fact that the Chamber once again adopted a new position regarding Al-Bashir's immunity. The Chamber ruled in 2011 that Al-Bashir does not enjoy immunity because of an exception under customary international law for the prosecution of international crimes by an international court like the ICC. ${ }^{125}$ The Chamber's decision in the Chad and Malawi cases are instructive in this regard, maintaining that no sitting Head of State could ever claim immunity before the ICC. In 2014, the Chamber revised its decision and ruled that the Security Council implicitly waived Al-Bashir's immunity in Resolution 1593 and, therefore, he could not enjoy immunity given that the Council issued a binding decision under Chapter VII of the UN Charter obliging Sudan "to cooperate fully with ... the Court." ${ }^{126}$ In the decision of 6 July 2017, the Chamber found that Al-Bashir does not enjoy immunity owing to the fact that the Security Council's referral placed Sudan in a similar position as a state party. Consequently, Al-Bashir was barred from raising the defence of immunity from arrest due to the provision of Article 27(2) of the Rome Statute which provides that immunities "... shall not bar the Court from exercising its jurisdiction." 127 In all three decisions, the Court arrived at the conclusion that, referral to the ICC by the Security Council has two effects namely, removal of personal immunities and, subjecting a non-party state to the jurisdiction of the ICC. Here, exceptions under Article 98(1) of the Rome Statute do not apply. ${ }^{128}$

In the major findings of the Appeal's Chamber of the ICC in the Jordan Appeal, the defence of immunity was further discredited. ${ }^{129}$ On 6 May 2019, the Appeal's Chamber held that "[t]here is neither State practice nor opinion juris that would support the exercise of Head of State immunity under customary international law vis-à-vis an international court" ${ }^{130}$ Contrariwise, the jurisdiction of

123 The Prosecutor v. Omar Hassan Ahmad Al-Bashir, ICC-02/05-01/09-302, decision under Art. 87(7) of the Rome Statute on the non-compliance by South Africa with the request by the Court for the arrest and surrender of Omar Al-Bashir.

124 The Prosecutor v. Omar Hassan Ahmad Al-Bashir, ICC-02/05-01/09-302.

125 The Prosecutor v. Omar Hassan Ahmad Al-Bashir, ICC-02/05-01/09-139-Corr, para. 43.

126 See Security Council Resolution 1593, 31 March 2001.

127 The Prosecutor v. Omar Hassan Ahmad Al-Bashir, ICC-02/05-01/09-302.

128 See EJIL Talk, 'The immunity of Al-Bashir: The latest turn in the jurisprudence of the ICC', available at: www.ejiltalk.org/tag/al-Bashir/ (last accessed 2 May 2019).

129 K. Claus, 'Preliminary Observation on the ICC Appeals Chamber's judgment of 6 May 2019 in the Jordan Referral re Al-Bashir Appeal', Occasional Papers Series, No. 8, 2019, p. 1-2.

130 The Prosecutor v. Omar Hassan Ahmad Al-Bashir, Judgment in the Jordan Referral re Al-Bashir Appeal, No. ICC-02/05-01/09 OA2, 6 May 2019, para. 113. 
an international court has never been bared as a result of recognition for Head of State immunity. ${ }^{131}$ The Chamber also stated that " $t$ the absence of a rule of customary international law recognizing Head of State immunity vis-à-vis international court is relevant [....] also for the horizontal relationship between states when a State is requested by an international court to arrest and surrender the Head of State of another State". ${ }^{132}$ Therefore, the Appeal's Chamber clarified that Al-Bashir's immunity was implicitly lifted by virtue of the Security Council resolution referring the situation in Darfur to the ICC. ${ }^{133}$ In this decision, the Chamber confirmed the legal validity of what has been termed the 'Security Council route' as developed in the Jordan and South Africa Non-Cooperation Decisions. ${ }^{134}$ The Chamber also upheld that such reasoning must be applied at the horizontal level to displace the immunity of a Head of State of a non-party State. ${ }^{135}$

Owing to the developments discussed above, the fact that Omar Al-Bashir was referred to the ICC by the Security Council in accordance with Chapter VII of the UN Charter is very crucial. By virtue of the Council's mandate to maintain international peace and security, there is a chance that Omar Al-Bashir's immunity as the Head of State in the Republic of Sudan might have been removed despite the fact that Sudan was not a party to the Rome Statute. ${ }^{136}$ Security Council Resolution 1593 referring the Darfur situation to the ICC directly implied that investigations and prosecutions would be conducted in accordance with the Court's statutory framework irrespective of alternative defences. ${ }^{137}$ Therefore, it is rational to argue that despite Sudan not being state party to the Rome Statute, she has obligations arising from the Statute by virtue of Security Council Resolutions as if it were a state party to the Statute. Put differently, it can be inferred that Sudan's Omar Al-Bashir is directly subjected to the ICC owing to Resolution

131 See the 'Joint Concurring Opinion of Judges Eboe-Osuji, Morrison, Hofmański and Bossa', ICC02/05-01/09- 397-Anx1, para. 52-174. See also para. 175-252.

132 The Prosecutor v. Omar Hassan Ahmad Al-Bashir, Judgment in the Jordan Referral re Al-Bashir Appeal, No. ICC-02/05-01/09 OA2, para. 114.

133 For further details, see the Joint Concurring Opinion of Judges Eboe-Osuji, Morrison, Hofmański and Bossa, paras. 76-174, 414-418. See also paras 175-252, 431-445.

134 See A. Galand, 'A Hidden Reading of the ICC Appeals Chamber's Judgment in the Jordan Referral re Al- Bashir', EJIL Talk, 6 June 2019. Available at: www.ejiltalk.org/a-hidden-reading-of-the-iccappeals-chambers-judgment-in-the-jordan-referral-re-al-bashir/ (last accessed 10 September 2019).

135 While the Appeals Chamber decision fosters the argument that customary international law does not allow Head of State immunity to bar the jurisdiction of an international court as advanced herein, some academics have expressed additional concerns to say, a court establish by an agreement between two States cannot nullify the immunity of the Head of State of a third state which is not a party to the agreement except by means of a Security Council Resolution. More to this has been engaged in a brief but topical debate provided by EJIL Talk. See D. Akande, S. Leila \& J. Dov, 'ICC Appeals Chamber Holds that Heads of State have no immunity under customary international law before international tribunals', EJIL Talk, 6 May 2019. Available at: www.ejiltalk.org/icc-appeals-chamber-holds-that-heads-of-state-have-no-immunity-undercustomary-international-law-before-international-tribunals/ (last accessed 16 October 2019).

136 Trendafilova, 2014, p. 31.

137 See Art. 13(b) of the Rome Statute read along with Art. 24 and 39 of the UN Charter. 
1593 of the Security Council and Article 27(2) of the Rome Statute. ${ }^{138}$ Secondly, the defence of immunity accruing to President Al-Bashir was implicitly lifted owing to the Council's decision that Sudan shall 'cooperate fully' with the Court. Such a decision emanating from the Council's Chapter VII mandate became the overriding law, the consequence of which Al-Bashir was barred from raising the defence of immunity due to Sudan's obligations under the UN Charter to comply with the Security Council orders to cooperate with the ICC. ${ }^{139}$

The ICC has on many occasions insisted that Resolution 1593 referring the Darfur situation to the Court was adopted as a Chapter VII mandate and hence imposed an obligation upon all UN Member States to cooperate towards its full implementation. In the Pre-Trial Chamber II decisions of 18 September and 10 October 2013, the Court, after receiving information about President Omar AlBashir's intended travel to the USA, Ethiopia and Saudi Arabia, called on the three states to arrest and surrender Al-Bashir should he enter their territory. ${ }^{140}$ The Chamber aligned its decision with the argument that as non-state parties, the USA, Ethiopia and Saudi Arabia had no direct obligations towards the ICC arising from the Rome Statute. ${ }^{141}$ However, the Chamber pointed out that Security Council Resolution 1593 (of 2005) imposed a duty on all UN Member States, including the relevant regional and international organizations to cooperate fully with the Court. ${ }^{142}$

Besides the defence of immunity, the unseating of Al-Bashir as the president of Sudan through a military coup seems to further complicate the question of accountability for the crimes committed against the people of Darfur. Going by the latest developments in Sudan, the Military Council maintain its decision that Bashir's fate will be decided by a democratically elected civilian government when they relinquish power after two years. ${ }^{143}$ On the contrary, the Chief Prosecutor of the ICC Fatou Bensouda, told the UNSC that the former status quo is over. Omar Al-Bashir has been deposed, arrested, detained and charged with domestic offences. ${ }^{144}$ She argued inter alia that Sudan remains under a legal obligation to transfer the suspect to the ICC to stand trial for crimes stipulated under the Rome Statute except otherwise, it can demonstrate to the judges of the ICC that it is willing and able to genuinely and effectively prosecute the suspect for the allege crimes. ${ }^{145}$ Joined in her argument, proponents of international criminal

138 Trendafilova, 2014. p. 31.

139 Ibid.

140 See Prosecutor v. Omar Al-Bashir, Pre-Trial Chamber II, Decision regarding Al-Bashir's potential travel to the USA, 18 September 2013, p. 6.

141 See Prosecutor v. Omar Al-Bashir, 2013. para. 11.

142 Ibid.

143 BBC News, 'Omar Al-Bashir: Sudan's ousted president', available at: www.bbc.com/news/worldafrica-16010445 (last accessed 11 October 2019).

144 Aljazeera News, 'ICC prosecutor: Omar al-Bashir must answer for Darfur abuses now', available at: www.aljazeera.com/news/2019/06/icc-prosecutor-omar-al-bashir-answer-darfur-abuses-190 619155025202.html (last accessed 11 October 2019).

145 France 24, 'Sudan's Bashir should be handed over or stand trial, says ICC prosecutor', available at: www.france24.com/en/20190619-international-court-sudan-bashir-trial-darfur-mass-killingsicc-army-protests-talks (last accessed 11 October 2019). 
justice hold the view that, in a transitional context, after a coup d'état characterized by military elites exerting control camouflaged as transition, a former ally cannot be prosecuted on the basis of impartiality. ${ }^{146}$ Also, Al-Bashir stands accused of genocide, crimes against humanity and war crimes which are exclusively within the jurisdiction of the ICC. ${ }^{147}$ His dethronement, arrest and detention by the Sudanese authorities provide a good opportunity for him to be transferred to The Hague for prosecution. ${ }^{148}$ It remains to be seen whether or not, AlBashir will be tried before the ICC.

\section{Instituting the Malabo Protocol}

\subsection{Historical Overview}

This portion of the article reflects on different historic epochs characterized by coordinating efforts from various judicial and political role players whose activities paved the way for the adoption of the Malabo Protocol. ${ }^{149}$ During the drafting of the African Charter on Human and Peoples' Rights (hereinafter the African Charter), Guinea proposed that there was need to establish a court in Africa to try perpetrators of human rights abuses and crimes under international law. ${ }^{150}$ Even though the idea was noble, it was deemed 'premature'. Rather, the African Commission on Human and Peoples' Rights (hereinafter the African Commission) was established. ${ }^{151}$ The possibility of a court was kept in abeyance pending the adoption of an additional protocol to the Charter. ${ }^{152}$ The question of an African criminal court resurfaced in 2004 when the issue of election of judges to the African Court on Human and Peoples' Rights (ACHPR) was brought before the AU Assembly. Fortunately, the question came at a time when positive institutional developments had occurred within the AU. Given that the African Commission could not on its own prosecute and convict the perpetrators of human rights violations, the $\mathrm{AU}$, in an earlier meeting adopted the Protocol of the Court of Justice of the African Union which embodied the judicial and operational framework for the African

146 Polity, 'Should Al-Bashir be prosecuted in the Hague or Sudan?', available at: www.polity.org.za/ article/should-al-bashir-be-prosecuted-in-the-hague-or-sudan-2019-04-24 (last accessed 11 October 2019).

147 BBC News, 'Omar Al-Bashir: Sudan's ousted president', (last accessed 11 October 2019).

148 Ibid.

149 C. Jalloh, K. Clarke \& V. Nmelielle, 'Introduction: Origins and Issues of the African Court of Justice of Human and Peoples' Rights', in C. Jalloh, K. Clarke and V. Nmelielle (Eds.), The African Court of Justice and Human and Peoples' Rights in Context: Development and Challenges, Cambridge University Press, 2019, p. 1-55.

150 Meeting of ministers, 7-19 January 1981 cited in Amnesty International Report, Malabo Protocol: Legal and institutional implications of the merged and expanded African Court, available at: www.amnesty.org/en/documents/afr01/3063/2016/en/ (last accessed 1 May 2019).

151 The African Commission on Human and Peoples' Rights is a quasi-judicial body inaugurated in 02 November 1987 and serve as a complaint and reporting mechanism to the African Court on Human and Peoples Rights, whose decisions are legally binding on the states parties.

152 Draft African Charter on Human and Peoples' Rights, prepared for the Meeting of Experts in Dakar, Senegal, 28 November - 8 December 1979, OAU/CAB/LEG/67/1, introduction, para. 4. 
Court of Justice. ${ }^{153}$ Similarly, the Protocol to the African Charter on the Establishment of an ACHPR came into force in January 2004 paving the way for the election of judges.

While the election of judges was expected to commence in July 2004, the number of candidates nominated were too small, failing to meet the requirements of the AU Assembly. ${ }^{154}$ The Assembly redirected its attention to another issue of substance when the then chairperson, Nigerian former President Olusegun Obasanjo, proposed a merger between the African Court of Justice and the ACHPR to form a court with criminal jurisdiction. ${ }^{155}$ In line with his proposition, the AU Assembly decided to merge the two courts into one, ${ }^{156}$ a decision that reversed an earlier position by the African Union Executive Council (AUEC) which had considered the question of the merger in July 2003 and resolved that the ACHPR shall remain a separate and distinct institution from the Court of Justice of the African Union. ${ }^{157}$

The committee of jurists established to advise the AU on the modalities of bringing former Chadian President Hissène Habré and co-perpetrators to justice compiled a report in which, the committee reflected not only the Habré case, but also elaborated on how the AU should in future deal with crimes under international law. ${ }^{158}$ On this note, the AU Assembly promoted the idea of an African Court endowed with criminal jurisdiction by adopting the Protocol on the Statute of the African Court of Justice and Human Rights (ACJHR) in July 2008. ${ }^{159}$ In 2009, the AU Assembly further requested the AU Commission and the ACHPR "to examine the implications of the Court being empowered to try international crimes such as war crimes, crimes against humanity and genocide, and report to the Assembly in 2010."160 The Pan African Lawyers Union (PALU), whose mandate was to provide recommendations on a legal instrument to amend the Protocol, submitted its report to the AU Commission in June and August 2010 along with an annexure to the June report which was the first draft of the Protocol.

153 Protocol of the Court of Justice of the African Union, Art. 2(2).

154 See Amnesty International, 'Malabo Protocol: Legal and institutional implications of the merged and expanded African Court', Index: AFR 01/3063/2016.

155 Report on the decision of the Assembly of the Union to merge the African Court on Human and Peoples' Rights and the Court of Justice of the African Union, Executive Council, Sixth Ordinary Session, 24-28 January 2005, Abuja, Nigeria, EX.CL/162, pp. 1-2.

156 Decision on the Merger of the African Court on Human and Peoples' Rights and the Court of Justice of the African Union, Assembly/AU/Dec.83(V).

157 Decision on the Draft Protocol of the Court of Justice, Executive Council, EX/CL/59(III).

158 'Report of the Committee of Eminent African Jurists on the Case of Hissène Habré', paras. 35 and 39. Available at: https://www.peacepalacelibrary.nl/ebooks/files/habreCEJA_Repor 0506.pdf. (last accessed 12 August 2020).

159 See Protocol on the Statute of the African Court of Justice and Human Rights adopted during the 11th Ordinary Session of the Assembly of the African Union in Sharm El-Sheikh, 1 July, 2008. Available at: https://www.african-court.org/en/images/Basic\%20Documents/ACJHR_Protocol .pdf. (last accessed 12 August 2020).

160 Decision on the implementation of the Assembly Decision on the abuse of the principle of universal jurisdiction, Decision Assembly/AU/Dec. 213(XII), 4 February 2009. See also Decision on the Implementation of the Assembly Decisions on the International Criminal Court, Assembly/AU/Dec.366 (XVII), para. 8. 
During the months of August and November 2010, the Pan African Parliament organized consultative workshops in South Africa with representatives of the AU organs and Regional Economic Communities (REGs) to discuss the draft prepared by PALU. The draft was also discussed in the meetings of government experts in Addis Ababa in November 2011.

Despite numerous consultative workshops and meetings, the AU Assembly failed to consider the Draft Protocol in its 19th ordinary session in July 2012. Rather, the Assembly requested the collaboration of the AU Commission and the ACHPR to evaluate the financial and structural implications arising from the expansion of the jurisdiction of the ACJHR, and propose a definition for the crime of 'unconstitutional change of government'. Among these two requests, the crime of 'unconstitutional change of government' was highly debated as a concise definition of the crime was hardly agreed upon. For instance, the AU Commission held a meeting in Arusha, the occasion in which the question emerged as to whether 'popular uprising' constituted the crime of 'unconstitutional change of government'. The compromise of the Arusha meeting reflected in a subparagraph of the definition of the crime of 'unconstitutional change of government' read as follows: 'Where the Peace and Security Council of the African Union determines that the change of government through popular uprising is not an unconstitutional change of government, the Court shall be seized of the matter' ${ }^{161}$

Despite numerous deliberations and compromises, the AUEC was not satisfied with the Arusha meeting. The AUEC further requested the AU Commission to conduct "a more thorough reflection in collaboration with the AU's Peace and Security Council on the issue of popular uprising in all its dimension," 162 requesting the AU Commission to submit another report on the financial and structural implications of expanding the jurisdiction of the ACJHR to try international crimes. ${ }^{163}$

While different stakeholders continue to work towards refining the definition of crimes contained in the Draft Protocol, Kenya, supported by the AU in 2013 made a request for the UN Security Council to defer proceedings against President Uhuru Kenyatta and his Deputy William Ruto for a period of one year. ${ }^{164}$ The request made in line with the complementarity principle was to allow the Government of Kenya to find internal solutions to the 2007/2008 post-election violence that wrecked the country as well as to bring the alleged perpetrators to justice using domestic justice mechanisms. The AU Assembly was deeply disappointed by the fact that the Security Council did not even consider the deferral

161 Report on the Workshop on the Definition of Crimes of Unconstitutional Change of Government and Financial and Structural Implications, AfCHPR/LEGAL/Doc.3, para. 12.

162 Decision on the Draft Protocol on Amendments to the Protocol on the Statute of the African Court of Justice and Human Rights, EX.CL/Dec.766 (XXII), para. 2.

163 Decision on the Draft Protocol on Amendments to the Protocol on the Statute of the African Court of Justice and Human Rights Doc.PRC/Rpt(XXV), EX.CL/Dec.766 (XXII), para. 3.

164 See Letters from the Permanent Representative of Kenya to the United Nations addressed to the Secretary-General and the President of the Security Council, S/2013/624, available at: https:// www.securitycouncilreport.org/atf/cf/\%7B65BFCF9B-6D27-4E9C-8CD3-CF6E4FF96FF9\%7D/ s_2013_624.pdf (last accessed 17 July 2018). 
request. ${ }^{165}$ As a consequence, the Assembly directed the AU Commission to conclude the process of extending the jurisdiction of the ACJHR. ${ }^{166}$

\subsection{Some Reflections on the Malabo Protocol}

It is indeed a noble gesture for African states to create a court with criminal jurisdiction and having strong operational and constitutional backing. Such a court will serve as an alternative institution to achieve justice for the victims of international crimes committed within and outside the continent of Africa. ${ }^{167}$ The ACJHR exhibits specific features that are not common in other judicial institutions. These include provision for an office of defence counsel established on an equal platform to the office of the prosecutor. ${ }^{168}$ Also, the inclusion of specific crimes peculiar to the continent of Africa is of relevance. This will not only strengthen the arsenal of justice within the region by sending a strong message to the authors of such offences but it will also serve as deterrence to future perpetrators. ${ }^{169}$ The Protocol also creates a Victims and Witness Unit within the Registry to ensure the security of victims and other appropriate assistance. ${ }^{170}$ In addition to these innovative developments, Article 46M of the Protocol establishes a Trust Fund "for legal aid and assistance and for the benefit of victims of crimes or human rights violations and their families," an example drawn from the ICC's Victims and Witness Unit as well as the Trust Fund. ${ }^{171}$

Owing to the developments discussed above, including some innovations not mentioned in this Article, the Malabo Protocol has been hailed by some scholars for advancing the rule of law in Africa. ${ }^{172}$ However, the Protocol carries along pitfalls that seem detrimental to the jurisdiction of the ACJHR. First of all, the jurisdiction of the court seems too broad, given that Article 28A of the Protocol adds ten additional crimes to the existing core crimes. ${ }^{173}$ Such additional crimes may seem too cumbersome for the Court to deal with given that it is an infant institution. Also, the inclusion of such crimes under the Protocol may prove unhealthy to the court because of the fact that it is lobbying the cooperation of states to come into force yet these crimes are much common within and across the governments of African states. Logically, such states may seem reluctant to entrap

165 Decision on the Progress Report of the Commission on the Implementation of the Decisions on the International Criminal Court, Assembly/AU/Dec.493(XXII), para. 6.

166 Decision on the Progress Report of the Commission on the Implementation of the Decisions on the International Criminal Court, Assembly/AU/Dec.493(XXII), para. 13.

167 See Sirleaf, 2017, p. 71-91.

168 See Malabo Protocol, Art. 2(4).

169 Sirleaf, 2017, p. 71-91

170 Malabo Protocol, Art. 22B(9)(a).

171 See Art. 46M of the Malabo Protocol read along with Art. 79 of the Rome Statute.

172 Report of Kenyans for Peace with Truth and Justice, 'Seeking justice or shielding perpetrators? An analysis of the Malabo Protocol on the African Court'. Available at: kptj.africog.org/wpcontent/uploads/2016/11/Malabo-Report.pdf (last accessed 15 April 2018).

173 The crimes include the following: Unconstitutional Change of Government; Piracy, Terrorism, Mercenarism; Money Laundering; Trafficking in Persons; Trafficking in Drugs; Trafficking in Hazardous Wastes; Illicit Exploitation of Natural Resources. 
themselves by signing the Protocol. ${ }^{174}$ Perhaps, this may be the reason for the poor turnout by African states to the Malabo Protocol which makes it ineffective at the moment. The Protocol is said to be effective after ratification by 15 African States. So far, 11 out of the 54 African states have signed but not ratified the Protocol. Admittedly, the Court's jurisdiction remains ineffective for the moment. ${ }^{175}$

Another contention in the Malabo Protocol is associated with the provisions of Article 46A bis which grant immunity from prosecution for sitting Heads of States and senior government officials. ${ }^{176}$ The problem with Article 46A bis is that the crimes protected by the shield of immunity often violate the norms of customary international law. ${ }^{177}$ From a logical perspective, individual conducts amounting to customary law offence will never qualify as part of the official functions of a Head of State. ${ }^{178}$ This position has been endorsed by the ICC Statute and the implication is that the Statute does not deviate from the existing rules of customary international law. ${ }^{179}$ The ICTY established that under customary international law individual persons may be prosecuted for the war crime of torture "whatever their official position, even if they are Heads of State or government ministers." 180 In the Arrest Warrant Case, the International Court of Justice (ICJ) held that immunity from prosecution does not mean impunity in respect of the crimes committed. ${ }^{181}$ The Court distinguished between criminal responsibility and jurisdictional immunity and went on to specify circumstances in which immunities enjoyed by certain public officials under international law would not bar a criminal prosecution. Among the points raised, the Court stressed that officials invoking immunity may be subject to criminal prosecution in certain international criminal courts such as the ICC. ${ }^{182}$

The decision of the ICJ was reiterated in 2004 by the SCSL. ${ }^{183}$ The Court noted that the ICJ's decision affording sovereign immunity to the Minister of Foreign Affairs of the Democratic Republic of the Congo applied to prosecutions of an official of state A in state B; that the SCSL is not a national Court of Sierra

174 Sirleaf, 2017.

175 Ibid.

176 D. Tladi, 'Article 46A Bis: Beyong the Rhetoric', in C. Jalloh, K. Clarke \& V. Nmelielle (Eds.), The African Court of Justice and Human and Peoples' Rights in Context: Development and Challenges, Cambridge University Press, 2019, p. 838; C. Eboe-Osuji, 'Administering International Criminal Justice through the African Court: Opportunities and Challenges in International Law' in C. Jalloh, K. Clarke \& V. Nmelielle (Eds.), The African Court of Justice and Human and Peoples' Rights in Context: Development and Challenges, Cambridge University Press, 2019, p. 838; AU, Protocol on the Statute of the African Court of Justice and Human Rights, July 2008.

177 A. Abass 'Prosecuting international crimes in Africa: Rationale, Prospects and Challenges', European Journal of International Law, Vol. 24, No. 3, 2013, p. 933-946.

178 See re 'Goering \& Others' (1946) 13 'International Law Reports' 203, 221 (noting that sovereign immunity does not apply to 'acts condemned as criminal by international law').

179 D. van der Vyver, 'Prosecuting the President of Sudan: A dispute between the African Union and the International Criminal Court', African Human Rights Law Journal, Vol. 11, 2011, p. 13.

180 The Prosecutor v. Anto Furund iya Case IT-95-I-T, 1998, para. 140.

181 Democratic Republic of Congo v. Belgium, dissenting judgment of Van den Wyngaert, ICJ 3, 2002, para. 60.

182 Ibid., para. 61.

183 The Prosecutor v. Taylor 128 International Law Reports 239, 2004. 
Leone but an international criminal court; ${ }^{184}$ and that the principle of sovereign immunity is "derived from the equality of sovereign states and therefore has no relevance to international criminal tribunals which are not organs of a state but derive their mandate from the international community." ${ }^{85}$ Judge Van de Wyngaert noted in her dissenting opinion in the Arrest Warrant Case that, "immunity should never apply to crimes under international law, neither before international courts nor before national courts." 186

In similar manner, the South African legislation implementing the ICC provides that a person who "[i]s or was a Head of State or government, a member of government or parliament, an elected representative or a government official" can be prosecuted in a South African Court for crimes within the subject matter jurisdiction of the ICC, "despite any other law to the contrary, including customary and conventional international law." 187 It is worthy of note that, the rules articulating sovereign immunity in the Arrest Warrant Case apply to prosecutions in a national Court. An obiter dictum in the Arrest Warrant Case and the ratio decidendi in the Prosecutor $v$. Charles Taylor made it clear that a head of state (and minister of foreign affairs) do not possess sovereign immunity against prosecution in an international tribunal. ${ }^{188}$

Consequently, Heads of States and senior government officials do not enjoy immunity from prosecution under the jurisdiction of the ICC. Article 98 is construed to the understanding that, if the surrender of an official of a non-party state enjoying sovereign immunity is made to rest squarely upon a waiver of that immunity by the non-party state concerned, it could be interpreted in practice as (citing the exact wording of Article 27(2)) "bar the Court from exercising its jurisdiction over such a person," since the ICC Statute does not permit trials in absentia. ${ }^{189}$ This interpretation is justified by the argument that non-parties states are not compelled to cooperate with the Court and cooperation evidently includes the waiver by a government of sovereign immunity of its officials. ${ }^{190}$ In the light of the arguments raised, it is evident that the provision of Article 46A bis-immunity from prosecution for sitting Head of States and senior government officials-only serves as a hindrance to the progress made in the realm of international criminal jurisprudence.

184 Democratic Republic of Congo v. Belgium, 2002, para. 42.

185 Ibid., para. 51.

186 Ibid., para. 36.

187 Implementation of the Rome Statute of the International Criminal Court, Act 27 of 2002, Sec 4(2)(a).

188 The Prosecutor v. Charles Taylor, Case No. SCSL-2003-01-I, Decision on immunity from jurisdiction; S. Nouwen \& W. Werner, 'Doing Justice to the Political: In International Criminal Court in Uganda and Sudan', European Journal of International Law, Vol. 21, No. 4, 2010, p. 941-965; C. Jalloh, The Sierra Leone Special Court and Its Legacy: The Impact for Africa and International Criminal Law, Charles C. Jalloh, (Ed.), Cambridge University Press, 2013; University of Pittsburgh Legal Studies Research Paper. Available at SSRN: https://ssrn.com/abstract=2318125 (last accessed 18 October 2019).

189 D van der Vyver, 2011.

190 Z. Wenqi, 'On co-operation by states not party to the International Criminal Court', International Review of the Red Cross, Vol. 88, No. 861, 2006, p. 87-110. 
Another issue of concern is the complementarity provision under Article 46H of the Protocol. ${ }^{191}$ The Article fails to create a nexus between the ACJHR and the ICC perhaps for the fact that the ICC Statute itself does not provide for regional complementarity. ${ }^{192}$ This position of the ICC Statute has generated negative feedback as reflected in the judicial framework of Article $46 \mathrm{H}$ of the Malabo Protocol which omits the necessary clause through which the ACJHR could be linked with the ICC. ${ }^{193}$ It is worthy of note that the AU has made significant efforts to work with the ICC on the idea of regional complementarity. For instance, Kenya submitted a proposed amendment to the Rome Statute to the Working Group on Amendments with respect to the Preamble of the Rome Statute. Presently, the Preamble of the Statute read, "Emphasizing that the International Criminal Court established under this Statute shall be complementary to national criminal jurisdictions." ${ }^{194}$ Kenya proposed that the Preamble be amended to read, "Emphasizing that the International Criminal Court established under this Statute shall be complementary to national and regional criminal jurisdictions." ${ }^{195}$ (Emphasis added.)

According to the Kenyan delegation, regional complementarity is not a way to oust the ICC. It is the opposite. The regional jurisdiction gets just the first bite. National jurisdiction may be difficult to exercise. Rather than spring-boarding [from national to international jurisdiction], the ICC would be what it was meant to be, the last resort. ${ }^{196}$ Through this lens, regional complementarity is considered to be a compelling concept. Even though the amendment is still pending, it is important for the ASP to work towards incorporating the proposal by the Kenyan delegation as well as the AU to revisit and amend Article $46 \mathrm{H}$ of the Malabo Protocol to provide a nexus between the ACJHR and the ICC. These are some of the challenges that need to be addressed for the ACJHR to come into force and function properly.

\section{Concluding Remarks}

Approximately seventeen years since the Court came into force; it has predominantly focused on prosecuting African defendants. All suspects awaiting trial

191 See Malabo Protocol, Art. 46H.

192 M. deGuzman, 'Complementarity at the African Court' in C. Jalloh, K. Clarke \& V. Nmelielle (Eds.), The African Court of Justice and Human and Peoples' Rights in Context: Development and Challenges, Cambridge University Press, 2019, p. 645.

193 C. Jalloh, 'Reflections on the indictment of sitting Heads of States and Government and its consequences for Peace and Stability and Reconciliation in Africa', Legal Studies Research Papers Series, Working Paper No. 2014-02, January 2014.

194 Rome Statute of the International Criminal Court (1998).

195 African Union Withdrawal Strategy, Draft 2 Version 12.01.2017, p.9. Available at: www.hrw.org/ sites/default/files/supporting_resources/icc_withdrawal_strategy_jan._2017.pdf (last accessed 15 October 2019); see also United Nations Depository Notification C.N.1026.2013TREATIESXVIII.10 of 14 March 2014 (Proposal of amendments by Kenya to the Statute).

196 International Criminal Court Assembly of States Parties, Report of the Working Group on Amendments, Fourteenth Session (18-26 November 2015) ICC-ASP/14/34, para. E, p. 3. 
before the Court are from the African continent and also, Security Council referrals stated under Article 13(b) of the Rome Statute have targeted Africans only. ${ }^{197}$ The sequence of events discussed in part three and four of this article justifies the purported allegations of an ICC bias against Africans. In all situations, the Court justified its intervention based on serious crimes committed in the respective regions in Africa. ${ }^{198}$ However, similar atrocities committed in other regions of the world (Europe and America) did not and have not received considerable attention from the Court. This article concludes from previous analysis that the launching of air strikes in Iraq and Afghanistan by USA and British forces under the Bush and Blair administrations constituted instances of war crimes for which the Court was expected to take decisive measures in accordance with its mandate arising from Article 13 of the Rome Statute. Also, the ongoing conflict in Syria has resulted in massive deaths, including the displacement of thousands of Syrians who continue to find safe heavens in neighbouring countries yet, the ICC continues to be silent in the face of such atrocities.

The arguments raised in this article form an informative background against which the AU resolved to find African solutions to African problems by instituting the Malabo Protocol. However, the Protocol seems to be politically inclined as Article 46A bis grants immunity for sitting heads of states. This provision rather serves the interest of political hegemons (head of states and senior government officials within the continent) who continuously improvised constitutional mechanisms to stay in power and shield themselves from criminal prosecution. This pattern of behaviour is the consequence of which, most of the leaders in Africa have stayed in power for thirty years and above. ${ }^{199}$ They continue to violate the very constitution they sworn to protect as well as killing the very citizens who look up to them for protection. Most often, they are dethroned through a coup d'état or a circle of violence in which, civilians suffer the most. Article 46A bis of the Malabo Protocol simply endorsed this position held by African leaders to the detriment of their citizens. This article recommends that Article 46A bis be amended such that the shield of immunity is lifted in the interest of justice. In the absence of such an amendment, states parties should revert to their obligations under Article 27 of the Rome Statute.

197 S. Monageng, Africa and the International Criminal Court: then and now, in G. Werle, L. Fernandez \& M. Vormbaum (Eds.), International Criminal Justice Series, Vol. 1, Springer Publication, TMC Asser Press, 2014, p. 15.

198 Ibid.

199 See Agence France-Press, 'Africa's longest-serving leaders', available at: mg.co.za/article/ 2017-08-21-africas-longest-serving-leaders (last accessed 20 June 2018). 